\title{
Networks, Social Capital and Development
}

Link to publication record in Manchester Research Explorer

\section{Citation for published version (APA):}

Hess, M. (2017). Networks, Social Capital and Development. In D. Richardson (Ed.), The International Encyclopedia of Geography: People, the Earth, Environment, and Technology (pp. 4760-4768). John Wiley \& Sons Ltd.

\section{Published in:}

The International Encyclopedia of Geography

\section{Citing this paper}

Please note that where the full-text provided on Manchester Research Explorer is the Author Accepted Manuscript or Proof version this may differ from the final Published version. If citing, it is advised that you check and use the publisher's definitive version.

\section{General rights}

Copyright and moral rights for the publications made accessible in the Research Explorer are retained by the authors and/or other copyright owners and it is a condition of accessing publications that users recognise and abide by the legal requirements associated with these rights.

\section{Takedown policy}

If you believe that this document breaches copyright please refer to the University of Manchester's Takedown Procedures [http://man.ac.uk/04Y6Bo] or contact uml.scholarlycommunications@manchester.ac.uk providing relevant details, so we can investigate your claim.

\section{OPEN ACCESS}




\section{Networks, social capital, and development}

\section{Martin Hess}

\section{University of Manchester, UK}

Development is a moving target. The 1980s saw a crisis in development studies, often referred to as the "development impasse," when both development theories and real-world developments posed serious challenges to existing models of development at the time. Today, the latest indicators underpinning the 2015 United Nations Millennium Development Goals show that while progress has been made in tackling extreme poverty and a range of other areas of development, any improvements are highly uneven socially and geographically. Such uneven development outcomes occur against a backdrop of neoliberal economic policies, the roll-back of the state and the rise of increasingly fragmented global production networks in what Manuel Castells (2003) calls the network society. As conventional, top-down and state-led forms of development have failed on many accounts, albeit with some notable exceptions especially in East Asia, new forms of alternative development strategies and networked forms of development activism (nongovernmental organizations (NGOs), grass roots movements) have come to the fore. Since the 1990s, this has brought ideas of social capital into the spotlight both in academia and policy circles, often viewed as a development panacea and championed by global organizations such as the World Bank (Potter et al. 2012).
Critics, however, argued that the increasing focus on networks and social capital only helped to obscure some fundamental insights from political economy with regard to poverty and inequality and lead to a de-politicization of the development discourse and practice. Consequently, social capital as a concept has received a very mixed reception in human geography and cognate disciplines ever since its inception by Pierre Bourdieu and its subsequent formulations by James Coleman and Robert Putnam, with the latter becoming especially influential in framing the debate. The next sections will in turn address the role of networks as organizing principle underlying economic, social, and spatial development; Bourdieu's ideas of social capital and the reproduction of power relations; Putnam's concept of social capital, trust, and collective action; and the uptake of social capital in development discourse and policy, before offering some concluding thoughts.

Networks, geography, and development

The notion of networks has become almost ubiquitous, in academia as much as in public discourse and the media. Today, it seems an almost universal mode of social, political, and economic organization, from global subcontracting networks and global production networks to terrorist networks like Al Qaida and Islamic State (IS), from transnational migrant networks and local ethnic business clusters to community unionism, activist networks, and NGOs. Networks are the primary structures and organizational forms through which the flows of goods, services, people, capital, and information

The International Encyclopedia of Geography.

Edited by Douglas Richardson, Noel Castree, Michael F. Goodchild, Audrey Kobayashi, Weidong Liu, and Richard A. Marston. (C) 2017 John Wiley \& Sons, Ltd. Published 2017 by John Wiley \& Sons, Ltd.

DOI: 10.1002/9781118786352.wbieg1097 
are organized and orchestrated (Grabher 2009). In human geography, since the 1990s, the rise of networks as analytical focus, ontological basis, and methodological foundation for research has found its expression in the so-called relational turn. This approach views networks neither purely as structures nor organizational forms situated between atomistic individual action and hierarchies, but as relational processes that produce observable patterns and outcomes in society and economy (Dicken et al. 2001). Network thinking and analysis has since then gained currency in a variety of subdisciplines, not least economic geography and, to a lesser extent, development geography.

Interest in networks was triggered in no small part by Mark Granovetter's (1985) seminal article emphasizing the social embeddedness of economic action. Stressing the importance of concrete personal relations and networks of such relations for the generation of trust between actors, he laid down a foundation for the analysis of networks, their governance, and associated economic and developmental outcomes (Hess 2004). All networks share some fundamental characteristics. First, they are based on reciprocity. Any exchange processes (of materials, money, information, etc.) take place within the context of mutual relationships and network embeddedness is determined by the architecture, durability, and stability of these reciprocal relationships. Second, and in contrast to other forms of organization like markets or hierarchies, networks are held together by a multiplicity of interpersonal and organizational ties of different strength, from strong and durable connections to what Granovetter calls "weak ties" allowing for greater flexibility and openness thus avoiding the danger of lock-in and network inertia. Third, actors in networks are mutually interdependent, and such interdependency impacts on the stability and durability of collaboration between network agents. Fourth, networks are shot through with (asymmetrical) power relations that govern them and shape the economic and developmental outcomes of network activities for various actors and the places they inhabit.

Network formation takes place at a variety of scales, from the local to the global, connecting some places while bypassing others. Contemporary networks are made from a complex addition, crossing and entanglement of economic activities, of social and intellectual communities with considerable developmental consequences for the places in which global production networks "touch down" or local networks emerge in situ. There is now a plethora of literature that addresses regional development processes through the lens of networked forms of social and economic organization. Studies of economically successful regions, like the so-called Third Italy, Silicon Valley in California, or clusters of economic activity in the German state of Baden-Württemberg, identified formal and informal network building as main drivers of development. Dense networks at the local scale have been referred to as producing "institutional thickness," creating the conditions for sustained economic growth, innovation, and development. Institutional thickness refers to a strong institutional presence, high levels of interaction in various political, social, and economic networks, defined governance structures of domination and patterns of coalition, and the mutual awareness of being involved in a common "regional" enterprise. Such conditions have been identified as key ingredients in creative milieus or innovative/learning regions, and, more recently, the thickness concept has been conceptually enhanced to theorize social innovation and community development (Moulaert and Nussbaumer 2006). Moreover, attempts to recreate such geographical clusters and emulate their success have become a policy 
mantra in many regions across the Global North and the Global South. However, there also has been a growing recognition that such regions do not exist in isolation and developmental outcomes are also increasingly dependent on transregional networks and the nature of connections with global production networks (Coe and Hess 2011). In other words, development in any place is determined by a variety of local and translocal networks and the associated flows of people (through migration), materials, capital, and knowledge.

The distribution of power among the various agents constituting social and economic networks is clearly paramount for developmental outcomes and the distribution of any benefits from network activities. However, it has been argued that the network concept and metaphor provokes a one-dimensional understanding of power (Prey 2012). Referring to the work of Castells, network thinking has led to an emphasis on exclusion and inclusion as a fundamental form of exercising power. Indeed, much of the recent literature on economic and social upgrading for firms and regions has highlighted the importance of engaging with global networks in order to capture value as a means for development. But such a focus on inclusion and exclusion - following Prey's argument - obscures the problem of exploitation, a still prominent feature of many global and local networks. What is needed, therefore, is a better understanding of the relations between processes of exclusion and exploitation, as well as inclusion and privilege. To this end, the following section turns to one conceptualization of social capital as developed by Pierre Bourdieu.

Social capital, class, and habitus

Societies and communities are not conflict-free or harmonious social structures, but made up of complex sets of asymmetrical power relations in various social fields such as class, gender, or race/ethnicity. Rooted in a structuralist tradition of social sciences and the sociology of conflict, Pierre Bourdieu was interested in understanding society and inequality, and more specifically the ways in which society and social relations are produced and reproduced. Understanding society as a plurality of social fields, he argues that the control of various forms of capital defines an actor's position within social networks and society more broadly (Siisiäinen 2000). These forms are identified as economic, cultural, symbolic, and social capital and which need to be seen not in isolation but in relation to each other in order to understand how social relations are reproduced. The positions of actors in social space are conceived of as both the cause and the effect of capital accumulation in its different guises and particularly social capital. Bourdieu (1986, 249-250) defines social capital as:

the aggregate of the actual or potential resources which are linked to a possession of a durable network of more or less institutionalized relationships of mutual acquaintance and recognition - or in other words, to membership in a group - which provides each of its members with the backing of the collectively owned capital, a "credential" which entitles them to credit, in the various senses of the word.

This definition highlights two important components of social capital. First, it is a resource based on social networks and group membership and therefore is a collective phenomenon rather than the result of individual efforts even if actors are actively exploiting its potential. Within a social network or association, each actor occupies different positions and consequently varying possibilities to activate social capital as a resource as well as appropriating related benefits in the form of economic, cultural, and symbolic capital. Actors' predispositions are fueled by inequality 
which is rooted in the differential distribution of capital in its various forms. These predispositions in turn are mobilized to legitimate the differential structure of society and the inequalities in capital accumulation between members (Tzanakis 2013). Second, and following from this, social capital is based on mutual cognition and recognition, thus taking on a symbolic character in the form of symbolic capital. Social classes formed on the basis of uneven access to resources and capital only become meaningful when accepted and internalized by members of society, normalizing and legitimizing existing uneven distribution of capital within and between classes and individuals. In other words, social, cultural, and economic capital becomes socially effective only through the process of translation into symbolic capital and the exercise of symbolic power.

In Bourdieu's account of social capital, social structures and institutionalized behavior are paramount (Bebbington 2009). Individual agency has to be accounted for in the context of structural constraints, which he theorizes through the concept of "habitus." As an embodied materialization of an actor's resources, or "internalized capital," habitus puts an emphasis on the nonreflexive aspects of practice beyond the conscious, or the habitual element of human agency (Holt 2008). Similar to the role of symbolic capital, habitus acts as a key mechanism for reinforcing views and perceptions of social structure and context as legitimate and obvious. Acquired during the process of socialization from early childhood onwards, habitus describes an actor's predispositions and forms the basis for the generation of practices within particular social fields. Consequently, the ways in which people engage in social networks and realize social capital can only be partly explained by rational choices or conscious decisions and is to a considerable extent influenced by individual dispositions and habitual practices of which the person may not be aware.

Social capital as developed by Bourdieu arguably provides an important contribution to the study of development by establishing a conceptual framework that helps to explain how social networks can contribute to the reproduction of socioeconomic inequality. Such a conceptualization has not been without its critics, however. Questions still remain about the explanatory power of social capital and the danger of succumbing to economic reductionism, underplaying the transformational potential of social capital. There are also unresolved theoretical and methodological issues of agency/habitus and aggregation in the form of class/class habitus. Despite these problems, social capital and habitus are useful analytical lenses through which to better understand the structural mechanisms as well as embodied practices of social network formation and the struggles over the appropriation of capital(s). Somewhat surprisingly, within human geography and development studies Bourdieu's ideas about social capital, class, and habitus have been taken up quite reluctantly so far, albeit with some exceptions, for instance, in studies of inner city gentrification, rural communities, and transnational migration. Rather, it was another concept of social capital that from the 1990s onwards attracted the attention of geographers, development scholars and, importantly, policymakers and development practitioners.

Social capital, networks, and trust

In 1993, Robert Putnam published a study of institutional performance, civic society, and economic development in Italy titled Making Democracy Work. Like other observers, he was intrigued by the divergent economic development trajectories of different regions of Italy, 
with a burgeoning economy in what became known as the Third Italy (northeast and central regions) and markedly lower growth rates or even decline in the old industrial heartlands (First Italy) and the Mezzogiorno in the south (Second Italy). Putnam's conclusion based on his institutional analysis was that the north displayed much higher levels of collaboration than the south. Putnam $(1993,130)$ summarized the key empirical findings as follows:

In the North the crucial social, political and even religious allegiances and alignments were horizontal, while those in the South were vertical. Collaboration, mutual assistance, civic obligation, and even trust - not universal, of course, but extending further beyond the limits of kinship than anywhere else in Europe in this era - were the distinguishing features in the North. The chief virtue in the South, by contrast, was the imposition of hierarchy and order on latent anarchy.

Economic prosperity and development in Italy's north were thus understood as an outcome of social capital emanating from networks based on three main components: trust, shared norms and social obligations, and civic engagement in the form of voluntary associations.

For Putnam, trust is a crucial element of and contributor to civil society. Essential to facilitate social cohesion, trust is also a prerequisite for political institutions and governments to be perceived as legitimate. Such an understanding of trust goes beyond immediate interpersonal relations and assumes a more generalized form, where citizens trust that their involvement in producing a common good for the wider community and society will be reciprocated through the development of positive communal relations (Siisiäinen 2000). In Putnam's own view, such generalized trust creates reciprocity and various forms of civic engagement, which in turn produce and strengthen trust, in effect constituting a virtuous circle of social capital formation that ultimately fuels socioeconomic development. In line with other conceptualizations of trust (see Murphy 2006), it is also indispensable to reduce risk and lower transaction costs in a complex and contingent environment. In that sense, trust serves as the lubricant for mutually beneficial social relations in the form of bridging and bonding forms of social capital. Bridging social capital establishes connections between geographically and/or socially distant groups and expands social networks, while bonding social capital increases cohesion within geographically and/or socially proximate groups. Unlike Bourdieu, Putnam's work provides a more contextual or "ecological" idea of social capital based on trust and mutual cooperation, instead of focusing on networks utilized for individual benefit and/or those that reproduce class structures and socioeconomic inequalities.

A second important element of social capital, and closely related to trust, is the role of norms and mutual obligations. Without a set of values that is shared by the members of a network or community, with the expectation of reciprocity, civic engagement erodes and becomes increasingly futile. Rather than resulting in a virtuous circle of social capital for the benefit of socioeconomic development, the absence of shared norms and values will result in a downward spiral of growing distrust and ultimately the disintegration of networks, community, and society. Voluntary associations constitute Putnam's third central element of social capital, and to him they are a major source of trust generation, along with establishing interpersonal ties. Civic activism and voluntary associations are theorized as the cornerstones of civil society and democratic systems, in line with earlier work by social theorists like Niklas Luhmann and, in particular, Alexis de Tocqueville. The latter's studies of American society in the nineteenth century - published in 1835 as 
"Democracy in America" - were highly influential for Putnam's own work on voluntary associations, democracy, and social capital in the United States for which he became famous after the publication of "Bowling Alone" (Putnam 2000).

What Putnam has developed, then, is a concept of social capital that represents a decidedly functionalist approach compared to Bourdieu's sociology of conflict. Putnam's emphasis on trust and shared norms portrays a notion of community based on common interest and he by and large ignores the unequal power relations inherent in any social relation. What is more, his approach to social capital tends to conflate the concepts of Gemeinschaft (community) and Gesellschaft (society) as developed by Ferdinand Tönnies, obscuring any social and economic tensions and struggles found even within successful regions. Instead, social capital is attributed to aggregate entities like regions, or even countries, without much consideration for social struggle between actors within these spaces. The strongest criticism leveled against theories of social capital, especially in Putnam's formulation, is their propensity for circular reasoning and tautology without establishing clear causal relationships. Social capital is at the same time cause and effect of positive socioeconomic development. As Tzanakis $(2013,7)$ puts it, “[a]1l features of public life purported to reflect high social capital are accounted for by the high stock of social capital in that region." And yet, Putnam's work has had considerable influence on policy formulation in the realm of (international) development.

\section{Development practice and social capital}

The first major international organization to enthusiastically endorse the concept of social capital as a guide for policy formulation was the World Bank (Bebbington 2009). Against the backdrop of the highly problematic and counter-productive structural adjustment programs by international financial institutions during the 1980s and amidst increasing calls for more participatory forms of development as opposed to the prevalent top-down development strategies, social capital came to be seen as a possible route toward a more socially "grounded" approach to development. Such an approach also chimed with the emerging discourse of sustainable development, following the report by the Brundtland Commission in 1987, "Our Common Future," as it offered a new metric in support of the so-called triple bottom line goals of sustainability: economic growth, social justice, and environmental protection. During the 1990s, social capital became one of the most popular development concepts, embraced by donors and development agencies in the Global North as much as by actors, activists, and NGOs in the Global South. Increasingly seen as "capital of the poor," the possibilities of promoting social relations at the grassroots level were seen as both progressive and empowering.

One result of efforts by international agencies to mainstream social capital approaches for development has been the livelihood assets framework, aiming to address, in particular, the problems of rural poverty and vulnerability (Potter et al. 2012). New methods like participatory rural appraisal were deployed in order to understand development at the local level better, and to integrate the voices of the people which often had been considered as "objects" of development intervention instead of active subjects following their own strategies and objectives. Social capital was a vital conceptual ingredient in producing such participatory frameworks and the language of "capital" also resonated well with the overarching narrative of "inclusive" capitalism that could make it work for the poor. Critics therefore argue that mobilizing Robert 
Putnam's concept in development policy and intervention entails adopting a "Pollyanna"-style conception of society that ignores the fundamental political-economic problems of unequal access to assets, property, and resources. As Radcliffe (2004, 522, emphasis in original) notes: "Ironically, when social capital is placed at the heart of development projects they can in fact backfire, causing the destruction of local "social capital" or sociopolitical clout and knowledge."

Applying social capital theory in a rather uncritical way to development policy and practice, then, has contributed to some serious shortcomings in mainstream livelihoods research (Sakdapolrak 2014). First, the incarnation of Putnam's concept often aids in reproducing imbalanced consideration of the structureagency relationship given that power and politics are not given the necessary attention. Second, social capital - like other forms of capital - is perceived as stock that can be utilized for economic and material benefits, without proper acknowledgment of the contested nature of assets. Third, while being useful in focusing on the local dimension of development there is a danger of neglecting translocal and transnational structures and dynamics and the ramifications of global processes for individual and collective livelihood strategies. A careful geographical, multiscalar approach to livelihood research and social capital formation is therefore essential.

Finally, the global financial crisis that has engulfed global society since 2007 has brought home the vulnerabilities of citizens not only in the Global South, but also an increasing polarization in the industrial and postindustrial countries of the Global North. Here, too, ideas of social capital have been mobilized by different groups with often incompatible goals. On the one hand, civil society and voluntary association are championed by some political elites as a means to compensate for the retreat of the state (for instance, the current British government-led "Big Society" discourse), while at the other end of the spectrum alternative forms of civil association are experimented with, as illustrated by the Occupy movements that have sprung up in numerous cities, from New York and London to Hong Kong. These examples illustrate the political and contested nature of social capital, its role in reproducing unequal social relations, but also its transformative potential.

\section{Concluding thoughts}

Networks and social capital have become important and influential concepts of understanding socioeconomic development in space. At the same time, both notions are highly contested with regard to their usefulness and explanatory power and in terms of their implications for the politics of development, economic, and social change. In geography, the surge of relational thinking has provided a strong basis for network analyses across various scales, from the global to the local, and the differential power relations that emerge from and are exercised within social and economic networks. While network ontologies and methodologies have made inroads in various subdisciplines of human geography - along with many other social sciences, the concepts of social capital as developed by Bourdieu and, in particular, Putnam have resonated most notably with development studies and geography, not least because of the uptake of Putnam's ideas in policy circles. This has created an ongoing controversy between academics who see social capital as formulated by Putnam as yet another theoretical justification for neoliberal development and the retreat of the state, and others who perceive it as a way of thinking that takes civil society actors seriously and helps promote 
more democratic societies and civic engagement (Bebbington 2009). Some observers have indeed reflected on the imminent "death" of social capital as a theoretical and heuristic tool (Radcliffe 2004). But rather than throwing out the baby with the bathwater and abandoning social capital theory altogether, there exists an opportunity to reframe the discourse of social capital and development in a way that sheds light on structural, political-economic conditions as much as social networks and civil society. A way forward therefore might be what Rankin (2002) called a "Marxian approach to social capital," critically (re-)engaging with Bourdieu's ideas of various forms of capital, habitus, and theory of practice. Sakdapolrak's (2014) recent attempt to re-energize livelihoods research in development studies and development geography - drawing on Bourdieu's theory of practice - can serve as an example of how networks, social capital, and development might be re-imagined in a more critical, constructive, and progressive way.

SEE ALSO: Civil society; Class; Community; Cultural capital; Development; Global production networks; Governance and development; Livelihoods; Relational assets; Social capital; Social movements

\section{References}

Bebbington, Anthony. 2009. "Social Capital." In International Encyclopedia of Human Geography, edited by Rob Kitchin and Nigel Thrift, 165-170. Amsterdam: Elsevier.

Bourdieu, Pierre. 1986. "The Forms of Capital." In Handbook of Theory and Research for the Sociology of Education, edited by John Richardson, 241-258. New York: Greenwood Press.

Castells, Manuel. 2003. The Rise of the Network Society, 2nd edn. Oxford: Blackwell.
Coe, Neil M., and Martin Hess. 2011. "Local and Regional Development: A Global Production Networks Approach." In Handbook of Local and Regional Development, edited by Andy Pike, Andrés Rodríguez-Pose, and John Tomaney, 128-138. London: Routledge.

Dicken, Peter, Philip F. Kelly, Kristopher Olds, and Henry Wai-chung Yeung. 2001. "Chains and Networks, Territories and Scales: Towards a Relational Framework for Analysing the Global Economy." Global Networks, 1: 89-112.

Grabher, Gernot. 2009. "Networks.” In International Encyclopedia of Human Geography, edited by Rob Kitchin and Nigel Thrift, 405-413. Amsterdam: Elsevier.

Granovetter, M. 1985. "Economic Action and Social Structure: The Problem of Embeddedness." American Journal of Sociology, 91: 481-510.

Hess, Martin. 2004. “'Spatial' Relationships? Towards a Reconceptualization of Embeddedness." Progress in Human Geography, 28: 165-186.

Holt, Louise. 2008. "Embodied Social Capital and Geographic Perspectives: Performing the Habitus." Progress in Human Geography, 32: 227-246.

Moulaert, Frank, and Jacques Nussbaumer. 2006. "The Social Region: Beyond the Territorial Dynamics of the Learning Economy." European Urban and Regional Studies, 12: 45-64.

Murphy, James. 2006. "Building Trust in Economic Space." Progress in Human Geography, 30: 427-450.

Potter, Rob, Dennis Conway, Ruth Evans, and Sally Lloyd-Evans. 2012. Key Concepts in Development Geography. London: SAGE.

Prey, Robert. 2012. “The Network's Blindspot: Exclusion, Exploitation and Marx's ProcessRelational Ontology." tripleC, 10: 253-273.

Putnam, Robert. 1993. Making Democracy Work: Civic Traditions in Modern Italy. Princeton: Princeton University Press.

Putnam, Robert. 2000. Bowling Alone: The Collapse and Revival of American Community. New York: Simon \& Schuster.

Radcliffe, Sarah. 2004. "Geography of Development: Development, Civil Society and Inequality - Social 
Capital is (Almost) Dead?" Progress in Human Geography, 28: 517-527.

Rankin, Katherine. 2002. "Social Capital, Microfinance, and the Politics of Development." Feminist Economics, 8: 1-24.

Sakdapolrak, Patrick. 2014. "Livelihoods as Social Practices - Re-Energising Livelihoods Research with Bourdieu's Theory of Practice." Geographica Helvetica, 69: 19-28.

Siisiäinen, Martti. 2000. "Two Concepts of Social Capital: Bourdieu vs. Putnam.” Paper presented at ISTR Fourth International Conference, Dublin, July $5-8$.

Tzanakis, Michael. 2013. "Social Capital in Bourdieu's, Coleman's and Putnam's Theory: Empirical Evidence and Emergent Measurement Issues." Educate, 13: 2-23.

\section{Further reading}

Bebbington, Anthony. 2008. "Social Capital and Development." In The Companion to Development Studies, edited by Vandana Desai and Rob Potter, 132-136. London: Hodder Education.

Hess, Martin. 2009. "Investigating the Archipelago Economy: Chains, Networks and the Study of Uneven Development." Journal für Entwicklungspolitik, 25: 20-37.

McIlwaine, Cathy. 2007. "From Local to Global to Transnational Civil Society: Re-Framing Development Perspectives on the Non-State Sector." Geography Compass, 1: 1252-1281.

Thompson, Grahame. 2003. Between Markets and Hierarchies: The Logics and Limits of Network Forms of Organization. Oxford: Oxford University Press. 